\title{
Enhancement of Heat Transfer in a Rouletted Copper Tube Employing Delta Winglet Twirled Type Insert
}

\author{
Mohammad Taukir Hossain, Nesar Ali, and Muhammad Sadekul Karim
}

\begin{abstract}
Heat transfer is a process or a system of thermal engineering that concerns the generation, use, conversion, transfer, internal or external molecular formation and exchange of thermal energy (heat) between physical systems. The research work has been experimented for the turbulent flow heat transfer in a tube having delta winglet twisted tape and then separately with water as working fluid. The test section consisted of a circular copper tube of $26.6 \mathrm{~mm}$ inner diameter, $900 \mathrm{~mm}$ length with five K-type thermocouples. Bulk temperature and pressure drops have been measured. Material of both the delta winglet twisted tape insert was stainless steel. Delta winglet twisted tape insert had a length of $795 \mathrm{~mm}$, width of $20 \mathrm{~mm}$, thickness of $2 \mathrm{~mm}$, pitch length of $120 \mathrm{~mm}$, twist ratio of 6 while wire coil insert had the same length as that of delta winglet twisted tape insert, wire diameter of $1 \mathrm{~mm}$, mean coil diameter of $22 \mathrm{~mm}$ and pitch length of $30 \mathrm{~mm}$. Heat transfer rate, convective heat transfer coefficient, Nusselt's number, friction factor and heat transfer efficiency have been calculated to analyze heat transfer performance of circular copper tube fitted with or without inserts in turbulent regimes $(4000<\operatorname{Re}<15000)$. Nusselt's numbers for combination of delta winglet twisted tape and wire coil insert, wire coil insert only, delta winglet twisted tape insert only increased by 1.29 to 1.47 , 1.19 to 1.34 and 1.10 to 1.15 times respectively than the plain tube. They increased by $17.95 \%$ to $27.61 \%, 15.97 \%$ to $20.20 \%$, $8.90 \%$ to $12.02 \%$ and average of $21.65 \%, 17.44 \%, 8.95 \%$ respectively than the plain tube. Heat transfer rates also increased by 1.12 to $1.20,1.06$ to 1.09 and 1.03 to 1.05 times respectively compared to the plain tube. Heat transfer efficiencies increased by $1.36 \%$ to $1.62 \%, 1.24 \%$ to $1.47 \%$ and $1.14 \%$ to $1.34 \%$ respectively compared to the plain tube. Friction factors increased by 1.44 to $1.62,1.34$ to $1.43,1.22$ to 1.27 times respectively compared to the plain tube. The delta winglet twisted tape was the best arrangement for the enhancement of heat transfer rate as compared to the other inserts.
\end{abstract}

Index Terms-Turbulent Flow; Delta Winglet; Twisted Tape; Bulk Temperature; Reynold's Number and Nusselt's Number.

\section{INTRODUCTION}

For the evaluation of the performance appraisal of corrective type heat exchanger it is indispensable to realize the tube side as well as shard side heat transfer. Heat exchanger is the machinery providing heat transfer within the interim of two or more fluids and they can be classified according to the mood of flow of fluid. Improvement of heat transfer performance includes heat transfer augmentation.

Published on May 24, 2018

Mohammad Taukir Hossain was with Chittagong University of engineering \& Technology (email: taukirhossain280@gmail.com)

Md. Nesar Ali was with Chittagong university of Engineering \& technology (email: nesarali455@gmail.com)

Muhammad Sadekul Karim was with Chittagong University of Engineering \& Technology (email: sadekulkarim076@gmail.com)
The performance of customary heat exchanger can be substantially exalted by a sufficient number of enhancement technics. An eminent deal of exploration endeavor has been devoted to flourish apparatus and perform experiments to prescribe under the circumstances which an enhancement technique would improve heat transfer. Heat transfer augmentation technology has been extensively employed to heat exchanger inflictions in various machinery systems refrigeration, automobile, process industries, HVAC system etc. The objective of the augmentation of heat transfer is to winnow or attune high heat fluxes. This consequence in entrenchment of heat exchanger size, which commonly leads to less outlay cost. Another convenience of this augmentation of heat transfer system procedure and whole machinery arrangement is that commutation of temperature driving force, which diminishes the entropy procreation and improves the second law efficiency [1]. On the other hand, the heat transfer enhancement governs heat exchangers to conduct at comparatively lower velocity but still perpetrate the analogous or even better and transcendental heat transfer coefficient. This means that a curtailment of pressure drop, resembling to relatively less handling cost may be accomplished. All these amenities have made heat transfer prolongation technology attractive and engaging in heat exchanger applications. In addition, for shell and tube type heat exchangers, the tube insert technology is one of the most common and most suited heat transfer augmentation technology. Using copper twirled tube insert technology, additional heat exchangers can often be abstained and thus cabalistic cost saving becomes quite possible. Furthermore, research it has been cleared that as a heat exchanger becomes crusted, the additional resistance to heat transfer improvements due to fouling or scaling [2], [3]. These labyrinths are more common and usual for heat exchangers using in chemical industries, marine and upgraded or banal aerodynamic shape modelled vehicle applications. In our research work the heat transfer rate can be improved by introducing a disturbance in the copper twirled tube fluid flow by several enhancement technologies.

\section{EXPERIMENTAL PROCEDURES}

For the enhancement of heat transfer rate at first Delta Winglet twisted tape insert of stainless steel was used. A long copper tube of $26.6 \mathrm{~mm}$ internal diameter and $30 \mathrm{~mm}$ outer diameter, of which length of $900 \mathrm{~mm}$ was used as the test section. A constant heat flux condition was maintained by wrapping nichrome wire around the test section and fiber glass insulation over the wire. This was used to heat the test section. Outer surface temperature of the tube was measured at five points of the test section maintaining equal distance 
from one point to another point by K-type thermocouples. Two thermometers were used at the inlet and outlet section of the tube for measuring the bulk temperatures. At the outlet section the thermometer was placed in a mixing box. Pressure drop was measured at inlet and outlet of the test section by using manometer. Open loop system of water supply was used. The rate of flow was measured with the help of Rotameter in the travelling path of inlet water. Two types of temperature were measured during the experiment. One regarding tube outer surface temperature and another one was water inlet-outlet temperature. Data was taken for only plain copper tube without insert and with insert.

\section{A. Test Section}

The test section is a smooth circular tube made of copper. In order to prevent leakage Teflon tape has to be used for the joining of the tube and after that M-seal was used. Then the tube was wrapped at first with mica tape before wrapping with nichrome wire spirally wounded uniformly around the tube. Then again mica tape, glass fiber tape, heat insulating tape (Nittoflon tape) was used sequentially over the wrapped nichrome wire [4].

\section{B. Heating Section}

The nichrome wire was used as the resistance wire for the winding of the heater. This was used to heat the test section. Power was supplied to heater form an AC source of 220 volts and it was made to 60 volts by using voltage regulator. The resistance of nichrome wire was used in this experiment is of $31 \Omega$.

\section{Measuring System}

In Flow Measuring System the rate of flow was measured with the help of Rotameter installed in the travelling path of inlet water. The Rotameter can measure maximum of 27 Liter/min of water. But if there is lack of pressure then it was less.

In Temperature Measuring System, two types of temperature were measured during the experiment. One regarding tube outer surface temperature and another one was water inlet-outlet temperature. Water inlet and outlet temperature was measured by installing two thermometers at inlet and outlet side of the tube respectively. Tube outer surface temperature was measured by attaching 5 thermocouple wire at same distance from one to another on the outer surface of the tube. For this purpose, K-type thermocouple was used. Another side of the thermocouple was attached to a device named as "thermocouple meter" to get the temperature [5].

\section{Heat Transfer Enhancement}

For the purpose of experiment at first Delta Winglet twisted tape insert of stainless steel was used. Their lengths are $795 \mathrm{~mm}$. Pitch length ' $\mathrm{y}$ ' of the Delta Winglet twisted tape is $120 \mathrm{~mm}$, its width ' $\mathrm{w}$ ' is $20 \mathrm{~mm}$ and thickness is 2 $\mathrm{mm}$. Twist ratio ' $\mathrm{y} / \mathrm{w}$ ' of Delta Winglet twisted tape is 6 . The depth of wing cut for the wings in both sides is $5 \mathrm{~mm}$, the depth of wing cut ratio is 0.25 .

\section{E. Water Supply System}

The work was done in "Heat Engine" laboratory which has its own water supply system. Here water supply system was used as open loop system. The water is stored first in a tank and then supplies to the copper tube through Rotameter by a pump providing a gate valve, to control the flow rate [6]. The Rotameter is connected to the inlet section of the tube. The outlet section is connected to the drain and thus it is an open loop system.

\section{F. Mixing Box}

Mixing box is comprised of an inlet and outlet section. In this experiment it is fixed in the outlet of the test section. The hot water coming from the test section is flow to the drain through that box. The water is going out with various small bores instead of a big hole. Due to heating on the outside of the tube there will produce thermal boundary layer for which it is not possible to find out average or uniform temperature without mixing box. So hot water is mixed thoroughly in the mixing box to get the average outlet temperature. Out let temperature was measured by thermocouple which was situated above the mixing box.

\section{G. Heat Transfer Enhancement using Insert}

Using insert into copper tube enhances heat transfer rate by creating obstacles in fluid flow. Then Making turbulence in fluid flow. Causing the flow to spiral along the tube length and disturb the entire flow field. Finally, increasing pressure drop which increased or generated little but significant heat energy.

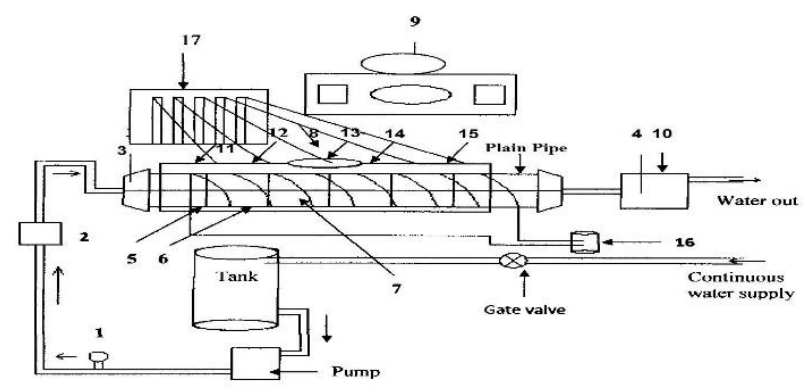

Fig. 1. Schematic diagram of the experimental setup
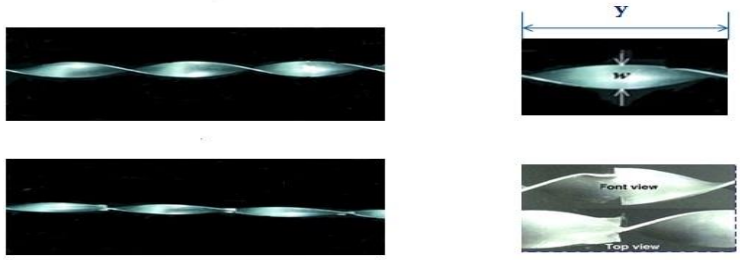

Fig. 2. Sketch of delta winglet twisted tape insert

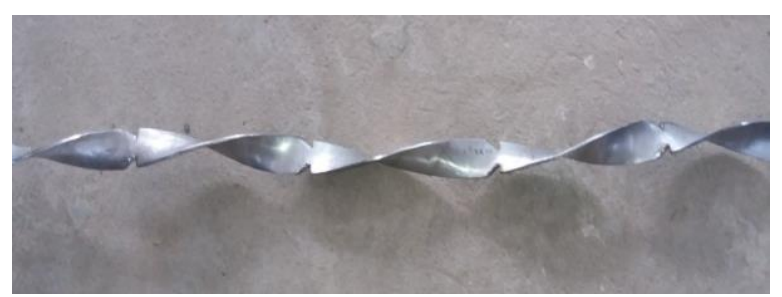

Fig. 3. Photographic view of delta winglet twisted tape insert 


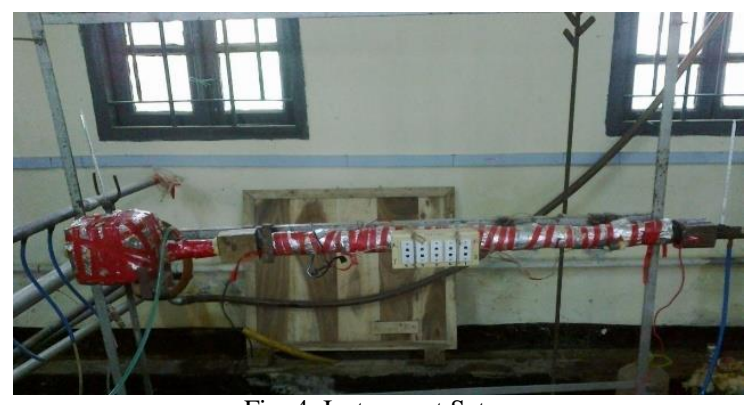

Fig. 4. Instrument Setup

\section{DATA COLLECTION \& ANALYSIS}

\section{A. Data Collection Method}

Calculation of convection heat transfer coefficient for turbulent flow is very complicated because the related formula is empirical and have error in the range of $\pm 10 \%$ to $\pm 25 \%$. At first water was made to circulate throughout the system by a pump and different flow rate were maintained by regulating Rota meter [7]. Then constant voltage was supplied to the heater by a voltage regulator and current was also supplied to the thermocouple monitor. When the temperatures in the inlet and outlet thermometer and thermocouple monitor became steady reading was taken for a given flow rate [8], [9]. Again increasing flow rate, in the same procedure next reading was taken. The flow rate was taken from $81 \mathrm{ml}$ per sec and increased by $15 \mathrm{ml}$ per sec up to $171 \mathrm{ml}$ per sec. In first step, data was taken for inserting the Delta Winglet twisted tape insert in the copper tube following the same procedure. The experimental study was conducted on passive heat transfer augmentation using delta winglet twisted tape insert, wire coil insert and combination of both of them in a circular copper tube having the specifications as listed below:

Tube inside diameter, $\mathrm{d}_{\mathrm{i}}=26.6 \mathrm{~mm}=0.0266 \mathrm{~m}$

Tube outside diameter, $\mathrm{d}_{\mathrm{o}}=30 \mathrm{~mm}=0.03 \mathrm{~m}$

Tube test length, $\mathrm{L}=0.90 \mathrm{~m}$

Thermal conductivity of copper, $\mathrm{k}=379 \mathrm{~W} / \mathrm{m}^{2}{ }^{0} \mathrm{C}$

Viscosity of water, $\mu=0.00087 \mathrm{~kg} / \mathrm{m} . \mathrm{s}$

Density of water, $\rho=1000 \mathrm{~kg} / \mathrm{m}^{3}$

Thermal conductivity of water, $\mathrm{k}=0.62 \mathrm{~W} / \mathrm{m}^{2}{ }^{0} \mathrm{C}$

Specific heat of water, $\mathrm{C}_{\mathrm{p}}=4179 \mathrm{~J} / \mathrm{kg} .{ }^{0} \mathrm{C}$

Outside surface area, $A_{o}=0.0848 \mathrm{~m}^{2}$

Inside surface area, $A_{i}=0.0752 \mathrm{~m}^{2}$

\section{B. Data Evaluation for Plain Copper Tube with DELTA Winglet Twisted Tape Insert}

Rotameter, inlet thermometer, outlet thermometer and five $\mathrm{K}$ type thermocouples gave different readings at different flow rates which are listed in the following tables.

\begin{tabular}{ccccc}
\multicolumn{6}{c}{ TABLE I: RotAMETER READING AT DIFFERENT FLOW RATE (WITH INSERT) } \\
\hline \hline $\begin{array}{c}\text { Obs } \\
\text { no. }\end{array}$ & $\begin{array}{c}\text { Rotameter } \\
\text { reading }(\mathrm{cm})\end{array}$ & $\begin{array}{c}\text { Flow rate } \\
(\mathrm{ml} / \mathrm{sec})\end{array}$ & $\begin{array}{c}\text { Flow rate } \\
\left(\mathrm{m}^{3} / \mathrm{sec}\right)\end{array}$ & $\begin{array}{c}\text { Flow rate } \\
(\mathrm{kg} / \mathrm{sec})\end{array}$ \\
\hline 1 & 5.4 & 84 & $0.84 \times 10^{-4}$ & 0.084 \\
2 & 7.4 & 111 & $1.11 \times 10^{-4}$ & 0.111 \\
3 & 9.4 & 141 & $1.41 \times 10^{-4}$ & 0.141 \\
4 & 11.4 & 171 & $1.71 \times 10^{-4}$ & 0.171 \\
5 & 13.4 & 201 & $2.01 \times 10^{-4}$ & 0.201 \\
6 & 15.4 & 231 & $2.31 \times 10^{-4}$ & 0.231 \\
7 & 17.4 & 261 & $2.61 \times 10^{-4}$ & 0.261 \\
\hline \hline
\end{tabular}

TABLE II: THERMOMETER AND THERMOCOUPLE READING AT DIFFERENT FLOW RATE (WITH INSERT)

\begin{tabular}{|c|c|c|c|c|c|c|c|}
\hline $\begin{array}{c}\text { Obs } \\
\text { no. }\end{array}$ & $\begin{array}{c}\text { Inlet } \\
\text { temp. } \\
\mathrm{T}_{\mathrm{i}} \\
\left({ }^{0} \mathrm{C}\right)\end{array}$ & $\begin{array}{l}\text { Outlet } \\
\text { temp. } \\
\mathrm{T}_{0} \\
\left({ }^{0} \mathrm{C}\right)\end{array}$ & $\begin{array}{l}\text { Thermo } \\
\text { Couple } \\
1,\left({ }^{0} \mathrm{C}\right)\end{array}$ & $\begin{array}{l}\text { Thermo } \\
\text { Couple } \\
2,\left({ }^{0} \mathrm{C}\right)\end{array}$ & $\begin{array}{l}\text { Thermo } \\
\text { Couple } \\
3,\left({ }^{0} \mathrm{C}\right)\end{array}$ & $\begin{array}{l}\text { Thermo } \\
\text { Couple } \\
4,\left({ }^{0} \mathrm{C}\right)\end{array}$ & $\begin{array}{l}\text { Thermo } \\
\text { Couple } \\
5,\left({ }^{0} \mathrm{C}\right)\end{array}$ \\
\hline 1 & 31.5 & 33.15 & 39 & 39 & 42 & 48 & 54 \\
\hline 2 & 31.5 & 33.05 & 38 & 38 & 42 & 48 & 53 \\
\hline 3 & 31.4 & 32.85 & 38 & 38 & 41 & 47 & 53 \\
\hline 4 & 31.3 & 32.65 & 37 & 37 & 41 & 46 & 52 \\
\hline 5 & 31.3 & 32.55 & 36 & 36 & 41 & 46 & 52 \\
\hline 6 & 31.2 & 32.35 & 35 & 35 & 39 & 45 & 50 \\
\hline 7 & 31.1 & 32.15 & 34 & 35 & 39 & 45 & 50 \\
\hline
\end{tabular}

Heat transfer rate $\mathrm{Q}$, mean velocity $\mathrm{U}_{\mathrm{m}}$, Reynold's number $\mathrm{Re}$ and convective heat transfer coefficient ' $h$ ' have been calculated and they are tabulated below:

TABLE III: CALCULATION OF Q AT DIFFERENT FLOW RATES (WITH

\begin{tabular}{cccc}
\multicolumn{4}{c}{ INSERT) } \\
\hline Obs no. & $\begin{array}{c}\text { Cross } \\
\text { Sectional } \\
\text { Area, } \mathrm{A}_{\mathrm{x}}\left(\mathrm{m}^{2}\right)\end{array}$ & $\begin{array}{c}\text { Velocity, Um } \\
\left(\mathrm{W} / \mathrm{m}^{2} \mathrm{C}\right)\end{array}$ & $\begin{array}{c}\text { Heat Transfer } \\
\text { rate, } \mathrm{Q}(\mathrm{W})\end{array}$ \\
\hline 1 & & 0.145 & 558.52 \\
2 & & 0.199 & 718.99 \\
3 & & 0.253 & 854.39 \\
4 & $5.56 \times 10^{-4}$ & 0.305 & 964.72 \\
5 & & 0.361 & 1049.97 \\
6 & & 0.415 & 1110.15 \\
7 & & 0.469 & 1145.25 \\
\hline
\end{tabular}

TABLE IV: CAlCUlation OF CONVECTIVE HeAt TRANSFER COEFFICIENT $\&$ REYNOLDS NUMBER (WITH INSERT)

\begin{tabular}{ccccccc}
\hline \hline & $\begin{array}{c}\text { Wall } \\
\text { Obs } \\
\text { temp } \\
\text { diff } \\
\left({ }^{0} \mathrm{C}\right)\end{array}$ & $\begin{array}{c}\text { Outer } \\
\text { Surface } \\
\text { Temp } \\
\left({ }^{0} \mathrm{C}\right)\end{array}$ & $\begin{array}{c}\text { Inner } \\
\text { Surface } \\
\text { Temp }^{\mathrm{n}} \\
\left({ }^{0} \mathrm{C}\right)\end{array}$ & $\begin{array}{c}\text { Bulk } \\
\text { Temp }^{\mathrm{n}}\end{array}$ & $\begin{array}{c}\left.{ }^{0} \mathrm{C}\right) \\
\text { transfer } \\
\text { Co- } \\
\text { efficient } \\
\left(\mathrm{W} / \mathrm{m}^{2} . \mathrm{k}\right)\end{array}$ & $\begin{array}{c}\text { Reynold's } \\
\text { Number }\end{array}$ \\
\hline 1 & 0.031 & 44.4 & 44.369 & 32.225 & 611.58 & 4433.3 \\
2 & 0.040 & 43.8 & 43.76 & 32.275 & 832.48 & 6084.4 \\
3 & 0.047 & 43.4 & 43.353 & 32.125 & 1011.89 & 7735.4 \\
4 & 0.053 & 42.6 & 42.547 & 31.975 & 1213.46 & 9325.4 \\
5 & 0.058 & 42.2 & 42.142 & 31.925 & 1361.58 & 11037.5 \\
6 & 0.062 & 41.4 & 41.338 & 31.775 & 1543.72 & 12688.5 \\
7 & 0.064 & 40.6 & 40.536 & 31.625 & 1709.05 & 14339.5 \\
\hline \hline
\end{tabular}

Experimental Nusselt's number $\mathrm{Nu}_{\text {exp }}$, Prandtl number $\mathrm{Pr}$ and theoretical Nusselt's number $\mathrm{Nu}_{\text {th }}$ have been calculated and percentage of increase in Nusselt's number while using inserts. Different pressure heads $\Delta \mathrm{h}$ have been found at different flow rates by using manometer. Using these values pressure drop $\Delta \mathrm{p}$, experimental friction factor $\mathrm{f}_{\exp }$ and heat transfer efficiency $\eta$ have been calculated and they are tabulated below.

\begin{tabular}{cccc} 
TABLE V: CALCULATION OF EXPERIMENTAL N \\
\hline \hline Obs No. PR \& & $\begin{array}{c}\text { Experimental } \\
\text { Nusselt's } \\
\text { Number, Nu }_{\text {exp }} \text { (WITH INSERT) }\end{array}$ & $\begin{array}{c}\text { Pradlt } \\
\text { Number, Pr }\end{array}$ & $\begin{array}{c}\text { Theoretical } \\
\text { Nusselt's } \\
\text { Number, Nu }_{\text {th }}\end{array}$ \\
\hline 1 & 26.23 & 5.87 & 38.85 \\
2 & 35.71 & 5.87 & 50.05 \\
3 & 43.41 & 5.87 & 60.65 \\
4 & 52.06 & 5.88 & 70.44 \\
5 & 58.63 & 5.88 & 80.61 \\
6 & 66.23 & 5.88 & 90.12 \\
7 & 73.32 & 5.89 & 99.38 \\
\hline \hline
\end{tabular}


TABLE VI: AVERAGE INCREASE IN NUSSELT'S NUMBER (WITH INSERT)

\begin{tabular}{ccccc}
\hline $\begin{array}{c}\text { Obs } \\
\text { No. }\end{array}$ & $\begin{array}{c}\text { Theoretical } \\
\text { Nusselt's } \\
\text { Number, } \\
\mathrm{Nu}_{\text {th }}\end{array}$ & $\begin{array}{c}\text { Experimental } \\
\text { Nusselt's } \\
\text { Number, } \\
\mathrm{Nu}_{\exp }\end{array}$ & Increase & $\begin{array}{c}\text { Average } \\
\text { Increase }\end{array}$ \\
\hline 1 & 38.85 & 26.23 & 12.62 & \\
2 & 50.05 & 35.71 & 14.34 & \\
3 & 60.65 & 43.41 & 17.24 & \\
4 & 70.44 & 52.06 & 18.38 & 19.1571 \\
5 & 80.61 & 58.63 & 21.98 & \\
6 & 90.12 & 66.23 & 23.89 & \\
7 & 99.38 & 73.32 & 26.06 & \\
\hline
\end{tabular}

TABLE VII: CALCULATION OF $\triangle \mathrm{P}$, THEORETICAL \& EXPERIMENTAL FRICTION FACTOR AND EFFICIENCY (WITH INSERT)

\begin{tabular}{cccccc}
\hline $\begin{array}{c}\text { Obs } \\
\text { No. }\end{array}$ & $\begin{array}{c}\text { Pressure } \\
\text { Head } \\
\text { diff, } \Delta \mathrm{h} \\
(\mathrm{m})\end{array}$ & $\begin{array}{c}\text { Pressure } \\
\text { diff, } \Delta \mathrm{P}\end{array}$ & $\begin{array}{c}\text { Experimental } \\
\text { Friction } \\
\text { factor, } \mathrm{f}_{\exp }\end{array}$ & $\begin{array}{c}\text { Theoretical } \\
\text { friction } \\
\text { factor, } \mathrm{f}_{\text {th }}\end{array}$ & $\begin{array}{c}\text { Efficiency, } \\
\Pi \%\end{array}$ \\
\hline 1 & 0.00316 & 181.875 & 0.511 & 0.040 & 28.90 \\
2 & 0.00162 & 215.979 & 0.322 & 0.036 & 33.39 \\
3 & 0.00185 & 247.506 & 0.228 & 0.033 & 37.60 \\
4 & 0.00201 & 268.933 & 0.170 & 0.032 & 41.02 \\
5 & 0.00222 & 296.208 & 0.134 & 0.030 & 44.00 \\
6 & 0.00240 & 320.670 & 0.110 & 0.029 & 46.14 \\
7 & 0.00260 & 347.49 & 0.093 & 0.028 & 47.46 \\
\hline
\end{tabular}

\section{RESULTS AND DISCUSSION}

\section{A. Results of Different Quantities for DELTA Winglet}

Twisted Tape Insert at Different Flow Rates \& Pressure Drops

Reynolds number, $\mathrm{Re}=4433.33 \sim 14339.54$

Heat transfer rate $\mathrm{Q}=558.52 \sim 1145.25 \mathrm{~W}$

Convective Heat transfer coefficient,

$\mathrm{h}=611.58 \sim 1709.05 \mathrm{~W} / \mathrm{m}^{2} . \mathrm{K}$

Experimental Nusselt's Number, $\mathrm{Nu}_{\exp }=26.23 \sim 73.32$

Experimental Friction factor, $\mathrm{f}_{\mathrm{exp}}=0.511 \sim 0.093$

Efficiency, $\eta=28.90 \% \sim 47.46 \%$

\section{B. Graphical Representation of Evaluated Values}

It has been found from the result that, in case of Delta Winglet twisted tape heat transfer rate increased with the increase of flow rate because more water was passing through the tube taking more heat gradually. Pressure drop also increased with the increase of flow rate in the surface of winglet. Heat transfer rate increased because water was flowing through the tube and developed two components of flow, axial component of flow and radial component of flow which were responsible for breaking down of water film, so the flowing water was taking more heat from the winglet. But pressure drop increased gradually with the increase of flow rate than the winglet. So, it is found that, where disturbance in water flow is greater, breaking down of this water film, heat carrying capacity, pressure drop is also more.

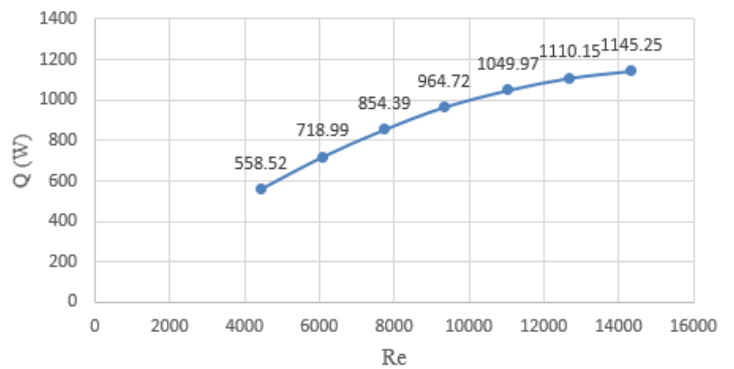

Fig. 5. Reynold's no. vs Heat transfer rate (DELTA Winglet Twisted Tape)

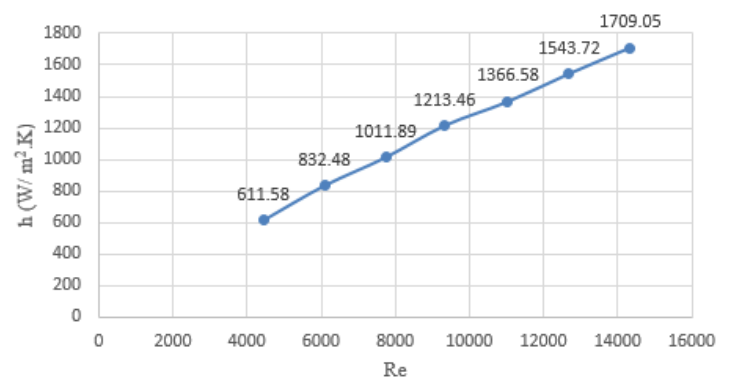

Fig. 6. Reynold's no. vs Heat transfer coefficient (DELTA Winglet Twisted Tape)

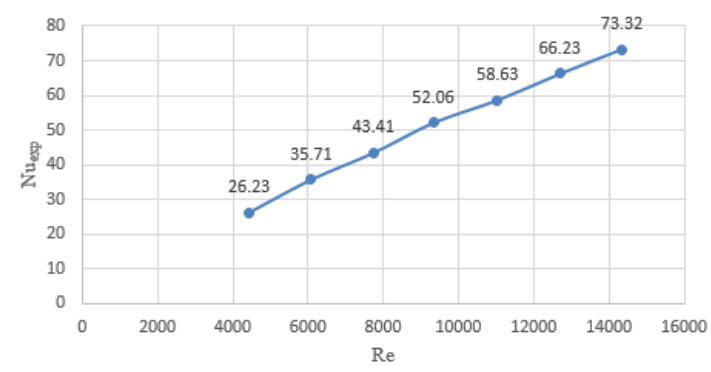

Fig. 7. Reynold's no. vs Experimental Nusselt's no. (DELTA Winglet Twisted Tape)

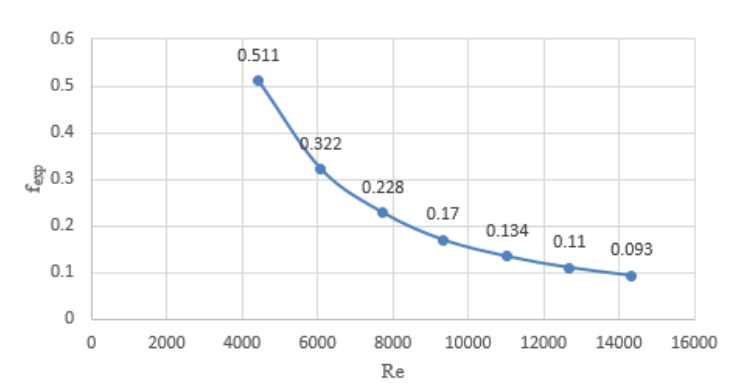

Fig. 8. Reynold's no. vs Experimental Friction factor (DELTA Winglet Twisted Tape)

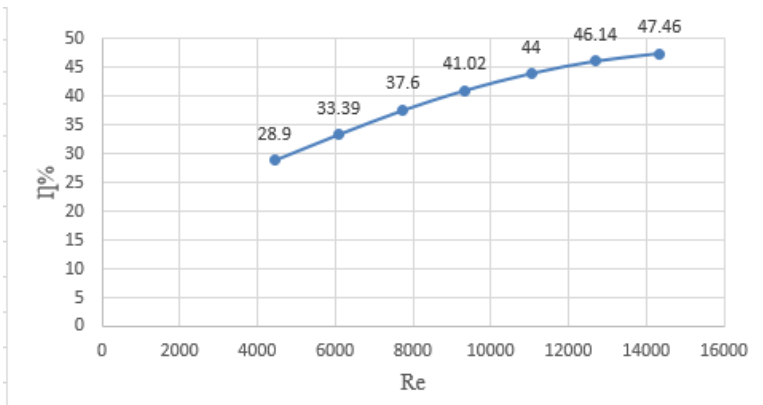

Fig. 9. Reynold's no. vs Efficiency (DELTA Winglet Twisted Tape)

From the graphical representation we can see that the value of Experimental Friction factor $f_{\exp }$ is relatively lower 
in case of using only delta winglet twisted tape insert. It is also seen that experimental friction factor $f_{\exp }$ decreases when Reynolds's number 'Re' increases. It is found from the Fig. 9 that heat transfer efficiency $\eta$ increases when Reynolds's number 'Re' increases.

\section{CONCLUSION}

The measurement of tube side heat transfer coefficient is an important part of heat transfer related subjects. Some of the more successful enhancement techniques currently used for heat transfer augmentation have been reviewed here. Several active techniques have been identified as possibilities for heat transfer enhancement. These techniques do require external power. But there is a power cost that needs to be considered. There are also passive techniques that have been identified as possibilities for tube side heat transfer enhancement. Insertion of twisted tape into a tube provides a simple passive technique for enhancing the convective heat transfer by introducing swirl into the bulk flow [10]. It may be guessed that the swirl flow helped in decreasing the boundary layer thickness. This study mainly focused on Reynolds number, Nusselt's number, friction factor and especially on heat transfer coefficient. Convective heat transfer coefficient continues to play an important role in heat transfer enhancement. The use of twisted tape is more effective in laminar region than transition and turbulent region.

\section{ACKNOWLEDGMENT}

The authors would like to be obliged to Chittagong University of Engineering and Technology for providing laboratory facilities and financial assistance.

\section{REFERENCES}

[1]. J.P Holman (2002) "Heat transfer", McGrew-Hill, International Edition published India.

[2]. ME Steinke \& SG Khandlikar(2004), "Single phase Heat Transfer Enhancement Techniques in Microchannel and Minichannel flows.", ASME $20042^{\text {nd }}$ International Conference on Microchannels and Minichannels.

[3]. A. E. Bergles (1995), "Techniques to augment heat transfer readings. Handbook of heat transfer applications", New York: McGraw Hill, chapter- 3 .
[4]. L. S. Sundar et. al (2012), "Effect of full length twisted tape inserts on heat transfer and friction factor enhancement with $\mathrm{Fe}_{3} \mathrm{O}_{4}$ magnetic nanofluid inside a plain tube: An Experimental Study",International Journal of Heat and Mass Transfer, Vol. 55, pp. 2761-2768.

[5]. S.K. Saha, U.N. Gaitonde, A. W.Date (1989), "Heat transfer and pressure drop characteristics of laminar flow through a circular tube fitted with regularly spaced twisted tape elements with multiple twists". Exp.Therm. Fluid Sci., Vol. 2, N0. 3, pp. 310-322.

[6]. S.K. Saha, A.Dutta, (2001), "Thermodynamic study of laminar swirl flow through a circular tube fitted with twisted tape elements". Journal of Heat Transfer, ASME, Vol. 123, No.3, 417-427.

[7]. S. Yadav (2008), "Experimental investigation of heat transfer performance of double pipe U-bend heat exchanger using full length twisted tape". International Journal of Applied Engineering Research (IJAER), Vol. 3, No. 3, 399-407.

[8]. G. F. Afzal, (2009), "Experimental Investigation of the tube side heat transfer enhancement using cross strip.", undergraduate project, Department of Mechanical Engineering, CUET.

[9]. M. N. Ozisik (2004), Heat Transfer, McGraw-Hill, International edition published by INDIA

[10]. M. M. Hasan (2010), "Experimental investigation of tube side heat transfer enhancement by using staggered pin", undergraduate project, Department of Mechanical Engineering, CUET.

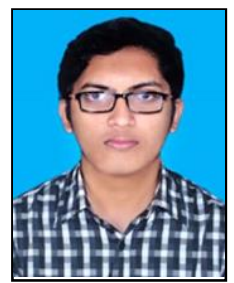

Mohammad Taukir Hossain was born in Bangladesh. He obtained BSc in Mechanical Engineering from Chittagong University of Engineering \& Technology (CUET) in 2017. His field of interest includes Heat Transfer, Applied Thermodynamics, Refrigeration, Aerodynamics and Reneable \& sustainable Energy.

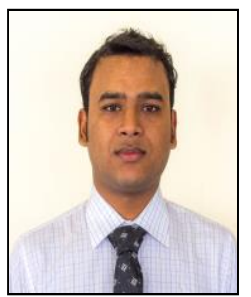

Md. Nesar Ali was born in Bangladesh. He obtained BSc in Mechanical Engineering from Chittagong University of Engineering \& Technology (CUET) in 2017. He has published a number of publication on different Peer reviewed article international research journal (AIP) and also published many conference proceedings in many international conference which held in Bangladesh. His field of interest includes Aerodynamics, Computational Fluid Dynamics, Renewable energy, Sustainable energy, Thermodynamics, Heat Transfer and Mechatronics.

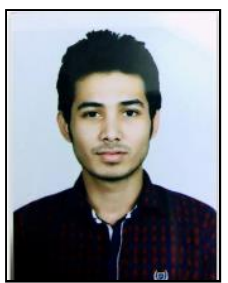

Muhammad Sadekul Karim was born in Bangladesh. He obtained BSc in Mechanical Engineering from Chittagong University of Engineering \& technology (CUET) in 2017. His field of interest includes Computational Fluid Dynamics, Heat Transfer Engineering Mathematics \& Geometry, Mechatronics, Engineering Operational research and Renewable Energy. 